\title{
Model Loyalitas Pasien Berbasis Kualitas Pelayanan Rumah Sakit Islam di Semarang
}

\author{
Muh. Abdurrouf ${ }^{1}$, Dyah Wiji Puspita Sari ${ }^{2}$ \\ ${ }^{1,2}$ Fakultas Ilmu Keperawatan, Universitas Islam Sultan Agung Semarang \\ Email: muh.abdurrouf@gmail.com
}

\begin{abstract}
Patient Loyalty Models Based on Islamic Hospital Service Quality in Semarang. Patient loyalty is very influential on the sustainability of the hospital. The loyalty of the patient is influenced by the patient's satisfaction with the overall service quality in which the satisfied patient returns to the service, and recommends to others. The purpose of this study was to analyze patient loyalty and develop models of patient loyalty improvement based on hospital service quality. The subjects of this study were inpatient at Islamic Hospital in Semarang area, sampling technique used was purposive sampling with 100 respondents. This research method was analytic survey method using cross-sectional approach. Data analysis techniques in this study used The Structural Equation Modeling (SEM) of AMOS 5.0 software package. The results of this study were nursing service, operational service, service quality, positively correlated with patient loyalty and showed a significant relationship. Medical services were positively associated with patient loyalty and show an insignificant relationship. Sex was positively related to medical services, but it did not show a significant relationship, while the relationship between sex with nursing services, operational services, overall service quality and patient loyalty did not significantly relate. The implications of this study can be a reference in improving the quality of services in hospitals so that patient loyalty to the hospital.
\end{abstract}

Keywords: Patient loyality, Quality service

\begin{abstract}
Abstrak: Model Loyalitas Pasien Berbasis Kualitas Pelayanan Rumah Sakit Islam di Semarang. Loyalitas pasien sangat berpengaruh terhadap keberlangsungan rumah sakit. Loyalitas pasien dipengaruhi oleh kepuasan pasien terhadap kualitas pelayanan secara keseluruhan dimana pasien yang merasa puas akan kembali menggunakan jasa pelayanan, serta merekomendasikan kepada orang lain. Tujuan penelitian ini adalah menganalisis loyalitas pasien dan menyusun model peningkatan loyalitas pasien berbasis kualitas pelayanan rumah sakit. Subyek penelitian ini adalah pasien rawat inap di Rumah Sakit Islam di wilayah Semarang, tehnik sampling yang digunakan adalah purposive sampling dengan jumlah 100 responden. Metode penelitian ini adalah metode survai analitik menggunakan pendekatan cross sectional. Tehnik analisis data dalam penelitian ini digunakan The Structural Equation Modelling (SEM) dari paket software AMOS 5.0. Hasil dalam penelitian ini adalah Pelayanan keperawatan, pelayanan operasional, kualitas pelayanan, berhubungan secara positif dengan loyalitas pasien dan menunjukkan hubungan yang signifikan. Pelayanan medis berhubungan secara positif dengan loyalitas pasien dan menunjukkan hubungan yang tidak signifikan. Jenis kelamin berhubungan secara positif dengan pelayanan medis, namun tidak menunjukkan hubungan yang signifikan, sedangkan hubungan antara jenis kelamin dengan pelayanan keperawatan, pelayanan operasional, kualitas pelayanan keseluruhan dan loyalitas pasien tidak berhubungan secara signifikan. Implikasi penelitian ini dapat menjadi acuan dalam meningkatkan kualitas pelayanan di rumah sakit sehingga loyalitas pasien kepada rumah sakit meningkat.
\end{abstract}

Kata kunci: Loyalitas pasien, Kualitas pelayanan

Era globalisasi telah menciptakan tantangan bagi semua jenis usaha untuk berkompetisi, termasuk usaha di bidang kesehatan. Dengan diberlakukannya masyarakat Ekonomi Asean (MEA) maka pihak asing akan banyak mendirikan Rumah sakit di Indonesia, pertumbuhan rumah sakit ini menimbulkan kompetisi yang semakin ketat dan pelanggan (customer) semakin mempunyai pilihan yang selektif, hal ini merupakan tantangan yang akan mempengaruhi keberlanjutan rumah sakit (Priyadi, 2015). Tantangan seperti ini mengharuskan para pelaku pelayanan kesehatan untuk berkompetisi dengan melakukan perubahan strategi dan perbaikan serta peningkatan kualitas pelayanan (Ravichandran, 2010).

Pasien sebagai konsumen rumah sakit menginginkan pelayanan yang lebih dan selalu 
tidak puas dengan pelayanan yang diberikan, kepuasan merupakan hasil penilaian pasien setelah membandingkan antara harapan dengan pelayanan yang diterimanya apabila sesuai harapan maka akan puas dan bila tidak sesuai harapan maka akan tidak puas (Wu, 2010), Studi yang dilakukan oleh Lee \& Yom (2007) menunjukkan adanya hubungan yang kuat antara kepuasan pasien terhadap pelayanan perawat dan dokter sehingga mereka kembali menggunakan jasa pelayanan rumah sakit. Loyalitas pasien dipengaruhi oleh kepuasan pasien terhadap kualitas pelayanan secara keseluruhan dimana pasien akan merasa puas dan kembali menggunakan jasa pelayanan, serta merekomendasikan kepada orang lain (Chahal, 2008).

Kualitas pelayanan secara keseluruhan yang diberikan oleh rumah sakit dapat mempengaruhi loyalitas pasien, hal ini sesuai dengan hasil penelitian yang dilakukan oleh Chahal (2008) bahwa kualitas layanan secara keseluruhan di rumah sakit antara lain kualitas pelayanan dokter dan perawat, pelayanan administrasi secara keseluruhan, atmosfir lingkungan, layanan teknis, kondisi kebersihan dan administrasi berpengaruh terhadap loyalitas pasien. Chahal (2008) mengemukakan bahwa dampak dari faktor social ekonomi seperti jenis kelamin dan pendapatan perlu diteliti untuk mengetahui pengaruhnya terhadap pelayanan rumah sakit dan loyalitas pasien.

Kualitas pelayanan medis berhubungan secara signifikan dengan kualitas layanan secara keseluruhan, kualitas pelayanan medis memiliki korelasi tertinggi diantara variabel lain yang berhubungan dengan kualitas layanan secara keseluruhan, variabel kinerja pelayanan yang paling sangat berkorelasi antara lain keramahan, menolong, query, kemampuan menjelaskan, kesediaan, pengendalian diri (Chahal, 2008). Hal ini juga disampaikan oleh Ravichandran (2010) yang menyatakan bahwa pelayanan medis berpengaruh secara signifikan terhadap kepuasan pasien.

Kualitas pelayanan secara keseluruhan juga dipengaruhi oleh kepuasan terhadap pelayanan yang diberikan oleh perawat dan kepuasan terhadap pelayanan perawat berpengaruh terhadap loyalitas pasien, hal ini sesuai dengan penelitian yang dilakukan oleh Chahal (2008) bahwa kualitas pelayanan perawat berhubungan secara signifikan terhadap kualitas pelayanan secara keseluruhan. Empat variabel layanan perawat yang paling penting untuk kepuasan antara lain ramah, memahami kebutuhan pasien, memperlakukan pasien seperti keluarga dan kontrol diri. Perawat yang professional, ikhlas, sabar, ramah, amanah dan istiqomah juga berpengaruh terhadap kepuasan pasien (Abdurrouf, 2013).

Tujuan penelitian ini adalah menganalisis loyalitas pasien dan menyusun model peningkatan loyalitas pasien berbasis kualitas pelayanan rumah sakit. Manfaat penelitian ini dapat menjadi acuan dalam meningkatkan kualitas pelayanan di rumah sakit sehingga loyalitas pasien kepada rumah sakit meningkat.

\section{METODE}

Jenis penelitian ini adalah penelitian kuantitatif. Metode penelitian yang digunakan dalam penelitian ini adalah menggunakan metode survai analitik menggunakan pendekatan cross sectional yaitu penelitian dengan melakukan pengukuran atau pengamatan pada populasi yang diamati pada waktu bersamaan, yaitu setiap subyek hanya dikenai satu kali pengukuran, tanpa dilakukan pengukuran ulang, untuk mengetahui pengaruh beberapa variabel terhadap loyalitas pasien di rumah sakit.

Variabel dalam penelitian ini terdiri dari 7 variabel yang terdiri dari Loyalitas Pasien, Kualitas seluruh pelayanan, Kualitas Pelayanan medik, Kualitas Pelayanan keperawatan, Kualitas operasional, Jenis kelamin. Penelitian ini dilaksanakan di Rumah Sakit Islam Sultan Agung Semarang dan di Rumah Sakit Roemani selama 2 minggu.

Populasi pada studi ini adalah seluruh pasien rawat inap di rumah sakit Islam di Semarang yang berjumlah 950, yang berada di RSI Sultan Agung dan RS Roemani (Bagian Rekam Medik, 2016). Kemudian metode pengambilan sampel dengan teknik purposive sampling, artinya berdasarkan karaktersitik populasi, yakni rumah sakit. Kemudian jumlah sampel (sample size) studi ini sebesar 100 responden.

Data yang didapatkan harus relevan dengan masalah yang akan diteliti dan dapat memberi jawaban terhadap permasalahan penelitian, sehingga diperlukan alat pengumpul data yang tepat dan baik. Penelitian ini menggunakan dua instrumen untuk dilakukan pengumpulan data. Instrumen A digunakan untuk pengumpulan data demografi, instrumen B digunakan untuk mengetahui model loyalitas pasien berbasis kualitas pelayanan Rumah Sakit Islam di Semarang. Instrumen pengumpulan data yang digunakan dalam penelitian ini adalah kuesioner yang bersumber dari Chahal (2008); 
Ravichandran (2010); Nadkarni (2008) yang telah dilakukan uji validitas dan uji reliabilitas. Kuesioner tersebut untuk menggali data tentang loyalitas pasien berbasis kualitas pelayanan Rumah Sakit. Jumlah item kuesioner terdapat 70 item pernyataan yang tediri dari 14 item untuk menggali data tentang pelayanan dokter, 14 item untuk menggali data tentang pelayanan perawat, 10 item untuk menggali data tentang fasilitas operasional, 8 item untuk menggali data tentang loyalitas pasien dalam menggunakan rumah sakit lagi (pengobatan sama), 8 item untuk menggali data tentang loyalitas pasien dalam menggunakan kembali pelayanan RS dengan sakit yang berbeda, 8 item untuk menggali data tentang pelayanan yang diberikan RS dibandingkan dengan RS Lainnya.

Untuk menganalisis data dalam penelitian ini digunakan The Structural Equation Modelling (SEM) dari paket software AMOS 5.0. Adapun langkah-langkah dalam SEM, Menurut Ferdinand (2000) adalah sebagai berikut : 1) Pengembangan model berbasis teori. 2) Pengembangan Path diagram. 3) Evaluasi Kriteria Goodnes-of-fit, 4) Pada langkah ini kesesuaian model dievaluasi, melalui telaah terhadap berbagai kriteria Goodnes-of-fit.

\section{HASIL}

Hasil penelitian tentang model loyalitas pasien berbasis kualitas pelayanan rumah sakit islam di semarang terdiri dari tabel yang meliputi karakteristik responden dan tabel hubungan antar variabel model loyalitas pasien berbasis kualitas pelayanan rumah sakit islam.

\section{Karakteristik Responden}

Tabel 1. Karakteristik Berdasarkan Jenis Kelamin

\begin{tabular}{ccc}
\hline Jenis kelamin & Frekuensi & \% \\
\hline Perempuan & 54 & 54 \\
Laki-laki & 46 & 46 \\
\hline
\end{tabular}

Tabel 2. Karakteristik Berdasarkan Umur

\begin{tabular}{ccc}
\hline Umur & Frekuensi & \% \\
\hline $17-25$ & 9 & 9 \\
$26-35$ & 27 & 27 \\
$36-45$ & 45 & 45 \\
$46-55$ & 12 & 12 \\
$56-65$ & 9 & 9 \\
$>65$ & 2 & 2 \\
\hline
\end{tabular}

Tabel 3. Karakteristik

Responden

\begin{tabular}{lcc}
\multicolumn{2}{c}{ Berdasarkan Pendidikan } & \\
\hline \multicolumn{1}{c}{ Pendidikan } & Frekuensi & \% \\
\hline SD & 22 & 22 \\
SLTP & 16 & 16 \\
SLTA & 47 & 47 \\
Perguran Tinggi & 15 & 15 \\
\hline
\end{tabular}

\section{Hubungan antar Variabel}

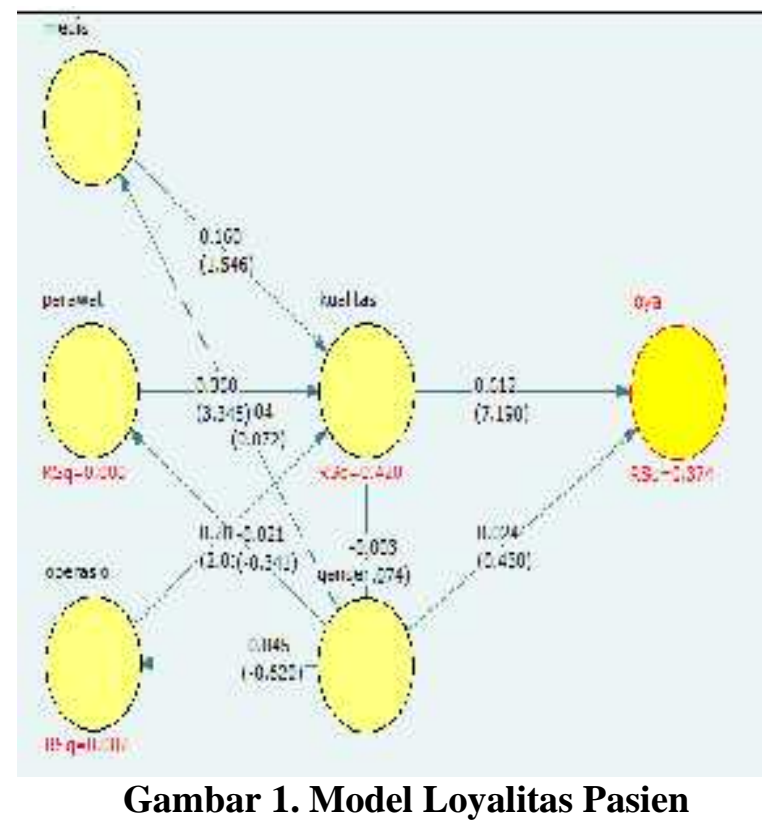

Loyalitas pasien Rumah Sakit Islam yang terdiri dari penggunaan kembali RS untuk pengobatan yang sama, penggunaan kembali untuk pengobatan berbeda dan perekomendasian kepada orang lain untuk menggunakan RS dipengaruhi secara signifikan oleh kualitas pelayanan secara keseluruhan yang terdiri dari pelayanan medis, pelayanan keperawatan, dan pelayanan operasional. Sedangkan jenis kelamin tidak berpengaruh secara signifikan terhadap pelayanan medis, pelayanan keperawatan, pelayanan operasional dan kualitas pelayanan keseluruhan serta loyalitas pasien.

Kualitas pelayanan keseluruhan dipengaruhi secara signifikan oleh pelayanan medis berupa sikap dokter yang ramah, selalu mendengarkan pasien, menjawab pertanyaan dengan memuaskan, dokter datang tepat waktu, komunikasi dokter dengan tenaga kesehatan yang lain baik, dokter mampu memberikan dukungan kepada pasien dengan baik. Kualitas pelayanan keseluruhan dipengaruhi secara signifikan oleh pelayanan keperawatan karena perawat care (peduli) kepada pasien, segera datang saat dibutuhkan pasien, ramah, selalu siap mendengarkan keluhan dan mampu memahami permasalahan pasien, perawat menjawab 
pertanyaan pasien dengan memuaskan, perawat selalu mendukung dan membantu pasien dan perawat berkomunikasi secara baik dengan dokter dan tenaga kesehatan yang lain.

Kulitas pelayanan keseluruhan dipengaruhi secara signifikan oleh pelayanan operasional berupa pelayanan bank darah yang efektif, fasilitas laboratorium yang baik, pembedahan dilakukan sesuai jadwal, spey/linen tempat tidur diganti tiap hari dan adanya interaksi yang baik dengan staf pelayanan di bagian depan.

a. Pengaruh pelayanan medis dengan kualitas pelayanan keseluruhan.

Pelayanan medis berhubungan secara positif dengan kualitas pelayanan keseluruhan dengan nilai koefisien korelasi 0,160, namun tidak menunjukkan hubungan yang signifikan karena nilai $\mathrm{t}=1,374$ yaitu di bawah nilai $t$ tabel $(1,66)$.

b. Pengaruh pelayanan keperawatan dengan kualitas pelayanan keseluruhan.

Pelayanan keperawatan berhubungan secara positif dengan kualitas pelayanan keseluruhan dengan nilai koefisien korelasi 0,380 , dan menunjukkan hubungan yang signifikan karena nilai $t=3,56$ yaitu di atas nilai t tabel $(1,66)$.

c. Pengaruh pelayanan operasional dengan kualitas pelayanan keseluruhan.

Pelayanan operasional berhubungan secara positif dengan kualitas pelayanan keseluruhan dengan nilai koefisien korelasi sebesar 0,20, dan menunjukkan hubungan yang signifikan karena nilai $\mathrm{t}=1,87$ yaitu di atas nilai t tabel $(1,66)$.

d. Pengaruh kualitas pelayanan keseluruhan dengan loyalitas pasien.

Kualitas pelayanan keseluruhan berhubungan secara positif dengan loyalitas pasien dengan nilai koefisien korelasi 0,66, dan menunjukkan hubungan yang signifikan karena nilai $t=11,39$ yaitu di atas nilai $t$ tabel 1,66 .

e. Pengaruh jenis kelamin dengan pelayanan medis, pelayanan keperawatan, pelayanan operasional, kualitas pelayanan keseluruhan dan loyalitas pasien.

f. Pengaruh jenis kelamin dengan pelayanan medis, pelayanan keperawatan, pelayanan operasional, kualitas pelayanan keseluruhan dan loyalitas pasien.

Jenis kelamin berhubungan secara positif dengan pelayanan medis dengan nilai koefisien korelasi 0,004, namun tidak menunjukkan hubungan yang signifikan karena nilai $\mathrm{t}=0,072$ yaitu di bawah nilai $\mathrm{t}$ tabel 1,66, Jenis kelamin berhubungan secara positif dengan loyalitas pasien dengan nilai koefisien korelasi 0,024 , namun tidak menunjukkan hubungan yang signifikan karena nilai $\mathrm{t}=0,430$ yaitu di bawah nilai $\mathrm{t}$ tabel 1,66, sedangkan hubungan antara jenis kelamin dengan pelayanan keperawatan, pelayanan operasional, kualitas pelayanan keseluruhan dan loyalitas pasien tidak berhubungan secara signifikan karena mempunyai nilai $\mathrm{t}$ di bawah nilai $\mathrm{t}$ tabel 1,66 .

\section{PEMBAHASAN}

Pelayanan medis berhubungan secara positif dengan kualitas pelayanan keseluruhan, namun tidak menunjukkan hubungan yang signifikan. Salah satu cara agar penjualan jasa pelayanan satu perusahaan lebih unggul dibandingkan para pesaingnya adalah dengan memberikan pelayanan yang berkualitas dan bermutu, yang memenuhi tingkat kepentingan konsumen (Rangkuti, 2016). Salah satu jasa pelayanan yang ada di rumah sakit adalah jasa pelayanan medis. Pelayanan medis yang berkualitas maka akan mendukung hasil kualitas pelayanan rumah sakit secara keseluruhan, sehingga memberikan dampak pada loyalitas pasien (Chahal, 2008). Kualitas jasa berhubungan positif dengan minat menggunakan ulang pelanggan (Lee, 2003).

Pelayanan keperawatan berhubungan secara positif dengan kualitas pelayanan keseluruhan dan menunjukkan hubungan yang signifikan. Pelayanan keperawatan merupakan bagian integral dari pelayanan kesehatan di rumah sakit yang mempunyai peranan besar terhadap pencapaian efisiensi, mutu dan citra rumah sakit di mata masyarakat (Alamsyah, 2011). Kualitas pelayanan keperawatan merupakan salah satu faktor penting dan fundamental khususnya bagi manajemen keperawatan dan para stakeholder-nya. Hal ini dikarenakan dampak dari service quality menentukan kualitas layanan kesehatan (Sari, 2009). Kualitas pelayanan keperawatan memberikan dampak terhadap kepuasan pasien. Hal ini sesuai dengan penelitian yang menunjukkan adanya hubungan antara kualitas pelayanan keperawatan dengan kepuasan pasien dengan $p$-value $(0,010)$ (Marthalena \& Nuryanto, 2017).

Pelayanan operasional berhubungan secara positif dengan kualitas pelayanan keseluruhan dan menunjukkan hubungan yang signifikan. Pasien pada umumnya mengembangkan loyalitas 
terhadap penyedia layanan berdasarkan pengalaman interpersonal yang signifikan yang mereka dapatkan dengan dokter dan perawat, dan kualitas pelayanan operasional rumah sakit. Kualitas pelayanan operasional memiliki dampak yang penting terhadap kualitas pelayanan secara keseluruhan yang mampu meningkatkan loyalitas pasien (Chahal, 2008).

Kualitas pelayanan keseluruhan berhubungan secara positif dengan loyalitas pasien dan menunjukkan hubungan yang signifikan. Hal ini sesuai dengan penelitian yang dilakukan oleh Niyarni, Ristiawati, Purnomo, Supriyo (2010) yang menunjukkan bahwa ada hubungan yang signifikan antaran kualitas pelayanan dengan minat menggunakan ulang pelayanan rawat jalan. Semakin tinggi nilai yang dirasakan konsumen maka akan semakin tinggi pula kesediaan konsumen tersebut untuk akhirnya membeli (Chapman dan Wahlers, 1999 dikutip dalam Puspitasari, 2006). Dengan adanya kualitas yang tinggi maka pelanggan akan memiliki minat untuk menggunakan kembali jasa dari provider yang sama ( $\mathrm{Li}$ dan Lee, 2001 dikutip dalam Puspitasari, 2006).

Hubungan antara jenis kelamin dengan pelayanan medis, pelayanan keperawatan, pelayanan operasional, kualitas pelayanan keseluruhan dan loyalitas pasien tidak berhubungan secara signifikan. Berdasarkan hasil analisa peneliti, semua orang baik laki-laki maupun perempuan sama-sama membutuhkan kualitas pelayanan yang sama baik pada pelayanan keperawatan, operasional, serta kualitas pelayanan secara keseluruha. Tanpa membedakan jenis kelamin, baik seorang lakilaki maupun perempuan akan memberikan loyalitas yang sama pada pelayanan yang berkualitas. Moenir (2002) mendefinisikan pelayanan sebagai kegiatan yang dilakukan oleh seseorang atau sekelompok orang dengan landasan tertentu dimana tingkat pemuasannya hanya dapat dirasakan oleh orang yang melayani atau dilayani, tergantung kepada kemampuan penyedia jasa dalam memenuhi harapan pengguna tanpa membedakan ras, jenis kelamin, asal-usul, dan identitas.

\section{SIMPULAN}

Pelayanan keperawatan, pelayanan operasional, kualitas pelayanan, berhubungan secara positif dengan loyalitas pasien dan menunjukkan hubungan yang signifikan. Pelayanan medis berhubungan secara positif dengan loyalitas pasien dan menunjukkan hubungan yang tidak signifikan. Jenis kelamin berhubungan secara positif dengan pelayanan medis, namun tidak menunjukkan hubungan yang signifikan, sedangkan hubungan antara jenis kelamin dengan pelayanan keperawatan, pelayanan operasional, kualitas pelayanan keseluruhan dan loyalitas pasien tidak berhubungan secara signifikan.

\section{SARAN}

Hal ini dapat di implikasikan bahwa penelitian ini dapat menjadi acuan dalam meningkatkan kualitas pelayanan di rumah sakit sehingga loyalitas pasien kepada rumah sakit meningkat.

\section{DAFTAR PUSTAKA}

Abdurrouf, M, Nursalam, \& Purwaningsih. 2013. Model Caring islami terhadap Peningkatan Kepuasan pasien. Jurnal Ners , 156-163.

Alamsyah. 2011. Manajemen pelayanan Kesehatan. Yogyakarta: Nuha Medika.

Chahal, H. 2008. Predicting Patient Loyalty and Service Quality Relationship: A Case Study of Civil Hospital. The Journal of Business Perspective, Vol 12 No.4.

Lee, Fred. 2003. To Build Loyalty, Hospitals Need to Exceed Customer's Expectation. Marketing Health Service, Summer, pp.3337.

Lee \& Yom. 2007. A Comparative Study of Patients' and Nurses' Perceptions of The Quality of Nursing Services, Satisfaction

and Intent to Revisit The Hospital: A Questionnaire Survey. International Journal of Nursing Studies, pp545-555.

Marthalena, Y \& Nuryanto, M. 2017. Hubungan Kualitas Pelayanan Keperawatan dengan Kepuasan Pasien di Rumah Sakit. Jurnal Ilmu Kesehatan, Vol. 2, No. 1, 2017, p.1722.

DOI: http://dx.doi.org/10.2304/jika.v2i1.2 8.g27.http://ejournal.stikesaisyah.ac.id/ind ex.php/eja

Moenir. 2002. Manajemen Pelayanan Umum Indonesia. Jakarta: Bumi Aksara.

Nadkarni, K. 2008. Evaluating MedicationRelated Services in A Hospital Setting Using The Disconfirmation of 
Expectations Model of Satisfaction. Research in Social and Administrative Pharmacy, (4) 12-22.

Niyarni, Ristiawati, Purnomo, I, Supriyo. 2010. Hubungan Kualitas Pelayanan dengan Minat Menggunakan Ulang Jasa Pelayanan Kesehatan Rawat Jalan di RSUD Bendan Kota Pekalongan. download.portalgaruda.org/article.php

Priyadi. 2015. Manajemen Rumah Sakit Menghadapi Era Masyarakat Ekonomi Asean Tahun 2015. Jakarta: http://www.indonesianqualityaward.org/ba ldrige-berdasarkan-sektor/healthcare/manajemen-rumah-sakit-menghadapiera-masyarakat-ekonomi-asean-th2015\#.VsCe4rR97Mw.

Puspitasari, D. 2006. Analisis Pengaruh Kualitas Pelayanan dan Kepuasan Pelanggan (Studi
Kasus Pada Maskapai Penerbangan Garuda Keberangkatan Semarang). Tesis, Fakultas Manajemen Universitas Diponegoro Semarang.

Rangkuti, F. 2006. Measuring Customer Satisfaction. Jakarta: Gramedia Pustaka Utama.

Ravichandran. 2010. Influence of Service Quality on Customer Satisfaction. International Journal of Business and Management, Vol. 5, No. 4; April 2010.

Sari. 2009. Manajemen: Pemasaran Usaha Kesehatan. Jogjakarta: Mitra Cendikia Press.

Wu, C. 2010. The Study of Service Gaps in The Hospital. Northeast Decision Sciences Institute Proceedings, 27-32. 